Resumen por el autor, Edmond Souchon.

Fsscuela Médica Tulane, New Orleans.

Una nueva solución permanente para la conservación de preparaciones anatómicas: la solución Souchon de cloruro cálcico.

Esta solución se compone de 3 onzas de cloruro cálcico granular puro U. S. P. que se añade a un galón de agua filtrada. Se agita la mezcla hasta disolución del cloruro y se filtra antes de usarla. Añádase 5 onzas de formol transparente a cada galón de la solución para impedir el enturbiamiento del líquido a consecuencia del desarrollo de bacterias y moho en la superficie. Si este último aparece aun a pesar de haberse añadido formol, debe separarse, agregando dos o tres cucharadas de pedacitos de timol o alcanfor. El símbolo de esta excelente solución es C3.F5. Es mejor que cualquier otro de los fluidos empleados hasta el presente y les supera en eficacia, simplicidad de composicion y baratura. Las preparaciones no le comunican color alguno. La solución no necesita cambiarse, como sucede con otras mezclas; una misma solución sirve para siempre. Solamente se necesita filtrarla una o dos veces para evitar su enturbiamiento, mientras que otras soluciones necesitan filtrarse varias veces. Antes de filtrar los filtros deben mojarse con agua filtrada, que después de pasar a través del filtro debe resultar completamente límpida. Si aún a pesar de la filtración la solución no resulta transparente, añádase medio dracma de sulfato alumínico pulverizado, agítese la mezcla y fíltrese. Esta solución sustituye a la mezcla de alcohol y glicerina, que es mucho mas cara. La descripción del método Souchon para la conservación de disecciones anatómicas se ha publicado en el Anatomical Record, Marzo 1917.

Translation by Jose F. Nonidez Carnegie Institution of Washingtun 


\title{
A NEW PERMANENT SOLUTION FOR THE PRESERVATION OF ANATOMIC PREPARATIONS, THE SOUCHON SOLUTION OF CALCIUM CHLORIDE
}

\author{
EDMOND SOUCHON
}

\author{
Tulane School of Medicine, New Orleans, Louisiana
}

The solution is composed of 3 ounces of pure granulated calcium chloride U. S. P. to 1 gallon of filtered water. Stir to dissolve and filter before using.

Add 5 ounces of clear white formol to each gallon of solution, to prevent cloudiness from bacterial development and mildewing at the top. Should mildew occur anyhow, remove the midlew and sprinkle the surface of the solution with two or three tablespoonfuls of tiny lumps of thymol or camphor. Camphor is much cheaper. C3.F5 is the symbol of this solution.

It is an ideal solution. It excels anything of its kind ever used before in efficiency, simplicity of composition, and cheapness. Preparations will not discolor it. The solution does not need to be changed as other solutions have to be, one solution will do for all time. It requires one or two filtrations for cloudiness, whereas other solutions require four or five or more. Before filtering the solution, filtered water must be run through the filters. The water must come out clear before filtering the solutions. Should some solution not filter clearly, add $1 / 2$ drachm of pulverized aluminum sulphate, stir and filter over.

The solution is quite cheap, about fourteen cents per gallon-four cents for the calcium and ten cents for the formol. When the old prices of calcium and formol return, the cost will be about ten cents per gallon of solution. This solution takes the place of the ultraexpensive alcohol and glycerine.

The description of the Souchon methods of preservation of anatomic dissections is described in the Anatomical Record published by The Wistar Institute of Anatomy of Philadelphia, November, 1915, and March, 1917.

The chemical method described in the November, 1915, number has been abandoned as being inferior to the newer curing method, described in the March, 1917, number.

Tulane University St. Charles Ave. 